\title{
Uma tomada de posição do cinema brasileiro em territórios urbanos (2009- 2017)
}

\author{
Vitor Zan \\ Universidade Federal do Mato Grosso do Sul \\ vitor.zan@ufms.br \\ https://orcid.org/0000-0002-1092-8537
}

RESUMO Este artigo de cunho panorâmico se interessa por três grupos de filmes bastante heterogêneos que permitem destacar a centralidade das questões de território urbano no cinema brasileiro recente (2009-2017). Apesar da diversidade de perspectivas, o habitar emerge, num vasto conjunto de obras, como ponto de convergência entre engajamento social e criação estética. Atrelada à dimensão política do espaço, a noção de território dá ensejo a um prisma analítico que responde às especificidades cinematográficas de filmes tão variados quanto $A$ vizinhança do tigre (2014), O som ao redor (2012), Branco sai, preto fica (2014), Um lugar ao sol (2009) e Que horas ela volta? (2015).

PALAVRAS-CHAVE Território; cinema brasileiro; habitar; cidade.

\section{Introdução: Uma guinada territorial}

O marco inicial deste estudo consiste em uma observação empírica que não nos é exclusiva. No início dos anos 2010, juntamente com uma série de críticos, cineastas e acadêmicos, notamos algo que se fortaleceria no cinema brasileiro durante toda a década e que hoje pode soar como um lugar-comum: uma das características mais marcantes compartilhada por diversos membros de uma nova geração de cineastas reside num interesse peculiar por questões eminentemente espaciais. Ecoando uma tendência mais ampla das ciências humanas, parte da cinematografia brasileira teria vivido um processo análogo ao que Jacques Lévy alcunhou de "spatial turn" (Lévy 1999). Um indício desse direcionamento se encontra nos próprios títulos dos filmes, que contêm amiúde topônimos reais ou imaginários, ou mesmo instâncias espaciais mais abstratas. É o caso, entre tantos outros, de Um lugar ao sol e Avenida Brasília formosa (Gabriel Mascaro, 2009, 2011); A cidade é 
uma só? e Era uma vez Brasília (Adirley Queirós, 2011, 2017); A vizinhança do tigre (Affonso Uchoa, 2014); O som ao Redor, Aquarius e Bacurau (Kleber Mendonça Filho, 2012, 2016, 2019); Baronesa (Juliana Antunes, 2018); ou mesmo Corumbiara (Vincent Carelli, 2009) e Serras da Desordem (Andrea Tonacci, 2006) - os dois últimos realizados por cineastas de gerações anteriores. Em muitos desses filmes, os espaços filmados deixam de ocupar o papel secundário que o cinema clássico lhes reservava: aquele de um receptáculo da ação, que devia geralmente passar despercebido (Bordwell, Thompson e Staiger 1988). Do roteiro à mise-en-scène, da montagem à plasticidade da imagem, os lugares filmados e a composição do espaço fílmico tornaram-se cruciais.

Entretanto, ao interrogar teoricamente a noção de espaço e suas aplicações no campo cinematográfico, percebemos que ela talvez não seja a mais oportuna para circunscrever o que ocorre em várias dessas obras. Isso porque em muitos filmes realizados por jovens brasileiros a partir de 2005, e sobretudo a partir de 2009, o apreço estético pelo espaço esteve intimamente ligado a um gesto de engajamento social. É o que se nota, por exemplo, em Corumbiara, em que o cineasta e indigenista Vincent Carelli recapitula sua luta contra latifundiários para fazer valer o primado do direito das populações autóctones sobre as terras por elas habitadas. É também o caso, embora em outro tipo de registro, de Branco sai, Preto fica (Adirley Queirós, 2014), em que homens negros, moradores da periferia de Brasília, são privados do direito de acessar à capital. Ou ainda de Aquarius, em que a faceta mais voraz do neoliberalismo patriarcal se encarna na figura de construtores imobiliários. Se é possível dizer, de forma geral, que o cinema brasileiro tendeu a se 're-engajar', esse processo esteve frequentemente atrelado a um viés territorial. Muito embora a filmografia mais recente apresente diferenças consideráveis em relação àquela dos anos 1960 e 1970, os liames urdidos pelo cinema moderno entre pesquisa formal e envolvimento político - liames que tenderam a se afrouxar durante o período da 'Retomada' - tornaram a vigorar nos tempos atuais. Mas a ênfase que antigamente se dava ao nacional e ao popular parece ter-se deslocado. Atrelada a conflitos históricos de classe, raça ou gênero, a faceta política dos lugares passou a ser auscultada e figurada com maior centralidade pelos cineastas, por meio de formas fílmicas variadas, ficcionais, documentais e experimentais. É esse dado fundamental que remete mais diretamente ao conceito de território do que àquele de espaço. 
A ideia de espaço é extremamente ampla e pode padecer de sua imprecisão. O espectro incluído na categoria espaço compreende todas as escalas, do imensamente grande ao infinitamente pequeno. Concerne a muitas disciplinas, como a arquitetura, a física, a geografia, a matemática, que tendem a visualizá-lo de maneiras distintas. Somente no âmbito do cinema, o espaço poderia designar elementos tão variados quanto a superfície plana da imagem, a profundidade de campo, o formato do quadro, a espacialidade tal como ela é percebida pelo espectador, ou ainda, fora dos filmes, os espaços de difusão ou as locações onde as obras são filmadas. Ora, em filmes como A cidade é uma só?, O som ao redor, Corumbiara ou Um lugar ao sol, algo mais específico está em jogo. Eles apontam mais diretamente para a noção de território, uma vez que essa implica as linhas de força exercidas sobre os lugares. É o que constatamos na "geografia do poder", de Claude Raffestin (1980), ou mesmo na forma como o termo foi utilizado historicamente. A locução latina territorium, segundo o geógrafo francês Yves Lacoste, "designou, primeiramente, na Idade Média, um certo número de feudos sobre os quais se estendia a autoridade de um poder eclesiástico, depois as terras em que se exerciam as leis e os poderes de um Estado" (Lacoste 2003, 379-380). Assim, o território, tal como o consideramos, é um conceito primordialmente político, ou geopolítico. Se pensarmos com Raffestin (1980), o espaço é anterior ao território. Aquele só se territorializa à medida que se torna objeto de ações e relações humanas e sociais, sendo por exemplo ocupado, nomeado, disputado, delimitado, historicizado e revestido de significados.

Tendo o cinema uma participação ativa na elaboração simbólica e histórica dos lugares, ele deve ser tomado mais como um agente na elaboração do território do que como seu decalque. Se nos limitarmos ao universo diegético, o espectro do território no cinema pode ser entendido como aquilo que, na forma e no conteúdo dos sons e das imagens, compõe a dimensão política dos espaços fílmicos. Fora dos filmes, ele concerne às linhas de força implicadas nos lugares e no contexto em que as obras são produzidas e distribuídas.

No caso particular do cinema brasileiro da última década, a territorialidade aparece sobretudo na esfera do morar. Isso ocorre tanto no modo como as próprias moradias são filmadas quanto nas experiências vividas por personagens-moradores. Com efeito, a escala do habitante foi escolhida pela maior parte dos realizadores. Fronteiras 
aparentes e transparentes foram salientadas - grades, muros, distâncias -, assim como situações de isolamento ou de expulsão. Diferentes tipos de conflito social tornaram-se visíveis através desse prisma. Em Branco sai, Preto fica, por exemplo, a dimensão territorial está fortemente associada ao racismo institucionalizado e revertido em violência de Estado. Já em Aquarius, ela é indissociável da questão de gênero. Embora estejamos conscientes de que esse fenômeno englobe filmes ambientados em zonas rurais (como no documentário Chão, de Camila Freitas, 2019) e em terras indígenas (vide Martírio, de Vincent Carelli, Tatiana Almeida e Ernesto de Carvalho, 2017), concentrar-nos-emos no contexto urbano, onde ele mobilizou o maior número de realizadores e de formas fílmicas, que estabelecem entre si um efeito de sistema.

Daremos destaque a três grupos de obras que podem ser tidos como ramificações dessa tendência mais ampla do cinema brasileiro recente. O primeiro é composto por filmes realizados por cineastas que moram em regiões periféricas e filmaram em seu próprio contexto residencial: Adirley Queirós, Affonso Uchoa e André Novais. O segundo grupo de obras, pelo contrário, é fruto de um esforço para se infiltrar em espaços fortificados restritos às elites. A obra paradigmática, aqui, é Um lugar ao sol, à qual se somam outros chamados 'filmes-dispositivo'. ' Já o terceiro grupo congrega longas-metragens de ficção que, de certo modo, visam elaborar uma síntese entre os dois outros, pois convocam a um só tempo regiões marginalizadas e bairros privilegiados, o que se dá notadamente através da presença de personagens subalternizados, como empregados domésticos, no contexto de residência de seus respectivos patrões. É o caso de O som ao Redor, Que horas ela volta? (Anna Muylaert, 2015) e Casa grande (Fellipe Barbosa, 2014).

Além de dar conta de diferentes realidades sócio-espaciais das cidades, das periferias aos bairros elitizados, essa estrutura tripartida reflete a primazia das relações de classe na abordagem do território urbano pelo cinema brasileiro, sem mascarar, contudo, outros tipos de conflito abordados pelos filmes. Tentamos enxergar, ainda, a importância histórica dos agrupamentos constituídos na trajetória do cinema brasileiro.

${ }^{1}$ Acerca do conceito de “filme-dispositivo", veja-se o artigo de Consuelo Lins (2007). 
Cabe findar esta nota introdutória indicando que este é um texto panorâmico, uma proposta de sistematização de um fenômeno que envolve filmes muito diversos, o que impede mergulhos aprofundados em obras particulares. O artigo chega também com algum retardo à língua portuguesa, pois é fruto de pesquisa anterior realizada fora do mapa da lusofonia (Zan 2019). Não contempla, portanto, eventos e filmes realizados a partir de 2017. Não obstante, visa contribuir para um debate instaurado no Brasil já há alguns anos.

\section{A emergência de um novo cinema "periférico"}

Os primeiros longas-metragens de Adirley Queirós e de André Novais, assim como $A$ vizinhança do tigre, de Affonso Uchoa, indicam a emergência de algo inédito no cinema brasileiro. $O$ fato de serem realizados em periferias metropolitanas por cineastas que nelas habitam talvez bastasse para distingui-los da maior parte da produção nacional, mas seria, sem dúvida, insuficiente para singularizá-los perante uma já antiga tradição brasileira de realização audiovisual na periferia.

No início dos anos 1980 veio à tona o chamado "vídeo popular" (Santoro 1989), visando fazer da recém-chegada tecnologia videográfica um instrumento de luta política acessível às classes marginalizadas. Já o chamado "vídeo comunitário" (Alverenga 2004), que se tornou mais expressivo nos anos 1990, deu mais ênfase ao aspecto pedagógico, com a finalidade de capacitar moradores de bairros periféricos para exercer atividades profissionais no setor do audiovisual. Contudo, os curtas-metragens realizados sob o amparo dessas iniciativas, geralmente com baixíssimo custo e estrutura mínima, tenderam a circular quase exclusivamente em pequenos circuitos associativos e militantes, ou em festivais destinados especificamente a obras portadoras de olhares subalternizados.

No caso de Queirós, Novais e Uchoa, uma série de filmes realizada por moradores de periferias em seu contexto de residência logrou acessar, pela primeira vez na história, um circuito de difusão e de financiamento de que obras congêneres sempre foram excluídas. Isso inclui editais de 
financiamento, ${ }^{2}$ grandes festivais de cinema nacionais e internacionais (em que foram selecionados e muitas vezes premiados), ou mesmo canais de televisão, salas comerciais e, mais recentemente, plataformas de vídeo sob demanda. Com efeito, o elemento comum que justifica o agrupamento (não exaustivo) de obras plurais não reside primeiramente na esfera da estética, mas num critério sócio-espacial, associado à circulação e ao reconhecimento de bens culturais.Tendo obtido mais de treze prêmios, o curta-metragem de conclusão de curso de Adirley Queirós, Rap, o canto da Ceilândia (2005), pode ser considerado como um pioneiro dessa inflexão, assim como seu longa $A$ cidade é uma só? É, todavia, no ano de 2014 que a dinâmica se notabilizou, com o lançamento de A vizinhança do tigre (Affonso Uchoa), Ela volta na quinta (André Novais) e Branco sai, Preto fica (Adirley Queirós).

Tal fenômeno se deve a razões variadas. Além da potência artística das obras e do talento individual dos cineastas, cumpre notar outro dado sociológico: embora não tenham beneficiado das políticas de cotas universitárias, os três realizadores lograram concluir o ensino superior em instituições de renome, fato bastante raro entre jovens habitantes de bairros periféricos. Ou seja, nenhum desses cineastas tem por formação principal os ateliês de curta duração, como costumam ser os cursos que se enquadram no chamado vídeo comunitário, o que não desmerece tais projetos. Dessa maneira, os filmes que melhor "saíram" das zonas marginalizadas foram realizados por sujeitos que também conseguiram ultrapassar barreiras sócio-espaciais impostas às populações periféricas. Como interpretar esse paralelismo? Seria ele indiciador de uma atenuação da segregação de certas periferias? Estariam o público dos grandes centros e as instituições “centrais"da segunda década do século XXI mais interessados pelo que lhes chegava das margens? Ou se trata, simplesmente, de um dado que reforça o caráter endógeno da cultura dominante, que só dialoga com o outro (periférico) quando esse incorpora os códigos por ela ditados?

Embora essas questões possam ser ponto de partida para interessantes investigações, o presente artigo se focará mais nas implicações do que

\footnotetext{
${ }^{2}$ Dentre os longas-metragens desses cineastas, A vizinhança do tigre é o único a ter sido contemplado unicamente com uma subvenção destinada à finalização. Entretanto, Affonso Uchoa obteve financiamento para seu filme anterior (Mulher à tarde, 2010), assim como para seu último trabalho (Arábia, 2017).
} 
nas origens deste fenômeno. Ainda assim, importa mencionar que Adirley Queirós, Affonso Uchoa e André Novais desfrutaram, em diferentes medidas, das políticas de descentralização da produção cultural encampadas, notadamente, pela gestão de Gilberto Gil no Ministério da Cultura a partir de 2003. Seus filmes são igualmente tributários de editais municipais e estaduais de fomento ao audiovisual, que surgiram nos anos 2000 em diferentes regiões brasileiras, corroborando a diversificação regional.

Em termos formais, os filmes mencionados, e vários outros, retiraram o monopólio da elaboração estética considerada de ponta aos grandes centros de classes médias e privilegiadas. Isso teve por corolário o reordenamento do imaginário das periferias tal como ele vinha sendo desenhado pela mídia e por parte do cinema brasileiro. Os bairros periféricos emergem mais frequentemente em sua pluralidade, dotados de especificidades sociais, urbanísticas e culturais. Deixam de ser vislumbrados unicamente sob o prisma pejorativo daquilo que falta. Em Ela volta na quinta, por exemplo, um subúrbio de Contagem, no Estado de Minas Gerais, é figurado como um local acolhedor, em que uma família de pessoas negras pode simplesmente viver seus dramas e amores. André Novais desloca, com isso, uma forma ou um gênero narrativo historicamente reservado a famílias brancas de classe média e alta, habitantes de bairros de maior poder aquisitivo. Esse deslocamento envolve a elaboração de uma estilística própria, que confere à trama um tipo de delicadeza e de senso de humor sem par na cinematografia nacional.

A periferia que se nota em Ela volta na quinta é um lugar onde, contrariamente às regiões mais verticalizadas das metrópoles, ainda é possível morar em casa, ter quintal, cachorro, prosear sentado na calçada, jogar futebol de campo e conversar com os vizinhos. Nesse sentido, é reveladora a cena em que o personagem André, interpretado pelo próprio cineasta, quando questionado por sua companheira sobre mudar de casa, se recusa veementemente a trocar o universo periférico por um bairro mais central. O personagem-cineasta inverte $\mathrm{o}$ paradigma hegemônico: "morar no centro é um negócio que... tipo, no centro que eu falo, no centro e proximidades, realmente eu não quero, desculpa" (01:07:02). A positivação do universo periférico não se confunde, porém, com uma idealização plena. Afinal, nesse mesmo diálogo, o casal reconhece o "inferno" que é o transporte público em alguns bairros periurbanos. Ela volta na quinta não deixa de sinalizar, 
em filigrana, o desalento provocado em Renato (Renato Novaes) pela sucessão de empregos deletérios, que não o permitem desenvolver um planejamento familiar satisfatório. Sem nunca assumir feições didáticas ou esquemáticas, o filme indica, ainda, através da personagem de André, a dificuldade de se consolidar como cineasta quando se pertence a uma família de baixa renda.

Nos longas-metragens mencionados, diferentemente da perspectiva da grande mídia, parcialmente endossada por filmes como Cidade de Deus (Fernando Meirelles e Kátia Lund, 2002) ou Notícias de uma guerra particular (João Moreira Salles e Kátia Lund, 1999), a violência nunca aparece de modo explícito. Quando ela é convocada, surge de modo indireto, e os moradores das margens são mais propriamente seus destinatários do que seus agentes. Em Branco sai, Preto fica, a violência recai sobre corpos negros, sendo perpetrada pelo próprio Estado por meio da polícia militar.

Já a mise-en-scène de Affonso Uchoa, em A vizinhança do tigre, opta por dissipar a violência na atmosfera de um bairro às margens de Contagem (o bairro Nacional). Ela paira, ronda, avizinha e assombra a juventude local desde o fora de campo. Ali, onde a urbanidade se confunde com a zona rural, Affonso Uchoa se debruça sobre a figura acometida pelo maior número de estigmas: o jovem periférico de sexo masculino, muito embora apenas um deles seja negro. Ao invés de ameaçador, como costuma acontecer, o pequeno grupo de rapazes que assume o protagonismo é visto como ameaçado. Ao mínimo deslize, eventualmente favorecido pela fase da adolescência ("a idade do tigre") e por condições sociais degradantes, a sua candura pode ser definitivamente sequestrada pelos tenebrosos caminhos da criminalidade. Contudo, em A vizinhança do tigre, nenhuma grande peripécia tem lugar. Uchoa opera uma desdramatização em prol da aproximação dos indivíduos, agora subjetivados, nuançados, filmados de perto, em planos esmerados que ressaltam a beleza de seus rostos.

Sem qualquer purismo documental, A vizinhança do tigre propõe ao espectador situações corriqueiras da vida desse grupo de jovens, incluindo passatempos, a preparação de uma refeição, a feitura de pequenos "bicos", brincadeiras viris, insultos amistosos, improvisações musicais, "papos retos", etc. Em baixa cadência, favorece a criação de vínculos entre o espectador e as personagens, desvelando, com a câmera frequentemente próxima aos corpos de Junim (Aristides de Sousa), Neguim (Wederson Patrício) e Menor (Maurício Chagas), seus 
traços culturais, sua beleza física e o teor da amizade que os une. Sem mudar de tom ou ceder ao melodrama, o filme revela que Junim já foi preso e Menor, ainda imberbe, é usuário de crack. E isso não é incompatível com o esforço que fazem para não serem mais um "nóia roubando na alta pra queimar na pedra" (00:02:38), ou para viver no salmo: "paz, justiça e liberdade" (00:03:04). Assim, A vizinhança do tigre se sustenta na corda bamba em que a juventude periférica é muitas vezes obrigada a caminhar.

As justaposições promovidas pela montagem estão pouco preocupadas em estabelecer relações de continuidade ou de causalidade. As sequências são relativamente autônomas e seu ordenamento responde preferencialmente à intensidade da performance dos corpos dos jovens e das interações entre eles. A vizinhança do tigre é elaborado de sorte que a falta de objetivo dos três protagonistas emane do próprio horizonte de expectativas, nada promissor, que a situação de exclusão lhes reserva. E essa ausência de perspectiva impossibilita a estrutura convencional de um drama. Desse modo, a condição marginalizada toma corpo na forma do filme, o que se nota ainda na escolha do cineasta de nunca filmar seus jovens personagens fora da periferia, na qual as habitações são precárias, os espaços de lazer escusos, os vínculos institucionais mínimos $\mathrm{e}$ as famílias globalmente desestruturadas.

Já Adirley Queirós, a partir de processos de criação coletiva, aposta na busca de especificidades periféricas capazes de atribuir poder de ação ou reação aos sujeitos subalternizados. Em todos seus filmes, recusa-se a restringir os sujeitos das margens à figura da vítima e compõe uma filmografia em que inventividade estética não é incompatível com ancoragem documental interessada na história social. Pelo contrário, elas se retroalimentam. É no terreno da história, nos arrabaldes da cidade-satélite de Ceilândia, que são cultivadas as fabulações mais fantasiosas. Tanto em A cidade é uma só? quanto em Branco sai, preto fica, o processo histórico, as diferenças de classe e de raça são amplamente 'territorializadas'. A antinomia entre as classes dirigentes e subalternizadas é refletida na oposição entre a cidade-satélite de Ceilândia e Brasília, que, enquanto capital brasileira, remete ao Estado e expande a alçada das alegorias. A cidade é uma só?, financiado por edital destinado à comemoração dos cinquenta anos de Brasília, atinge a capital brasileira aniversariante ao desvelar que a cidade-satélite de Ceilândia foi criada na virada dos anos 1960/1970 por conta da 
expulsão de dezenas de milhares de famílias de bairros populares de Brasília. Como apontou Cláudia Mesquita (2011), o filme conjuga estratégias dramáticas e documentais para indicar que as injustiças de outrora reverberam na Ceilândia de agora, como mostram os casebres e as ruas de terra enfatizados pelas composições dos planos do filme. Acrescentam-se também os longos trajetos de ônibus feitos pelo protagonista Dildu (Dilmar Durães) para ir trabalhar em Brasília, onde exerce a profissão de faxineiro, ou ainda os vários planos gerais em que o personagem é miniaturizado ante a vastidão de terrenos baldios atravessados a pé. Além de sugerirem o inabitável, esses planos trazem visualmente o argumento de que, nesse contexto, a falta de espaço não é o principal fator de exclusão da população pobre.

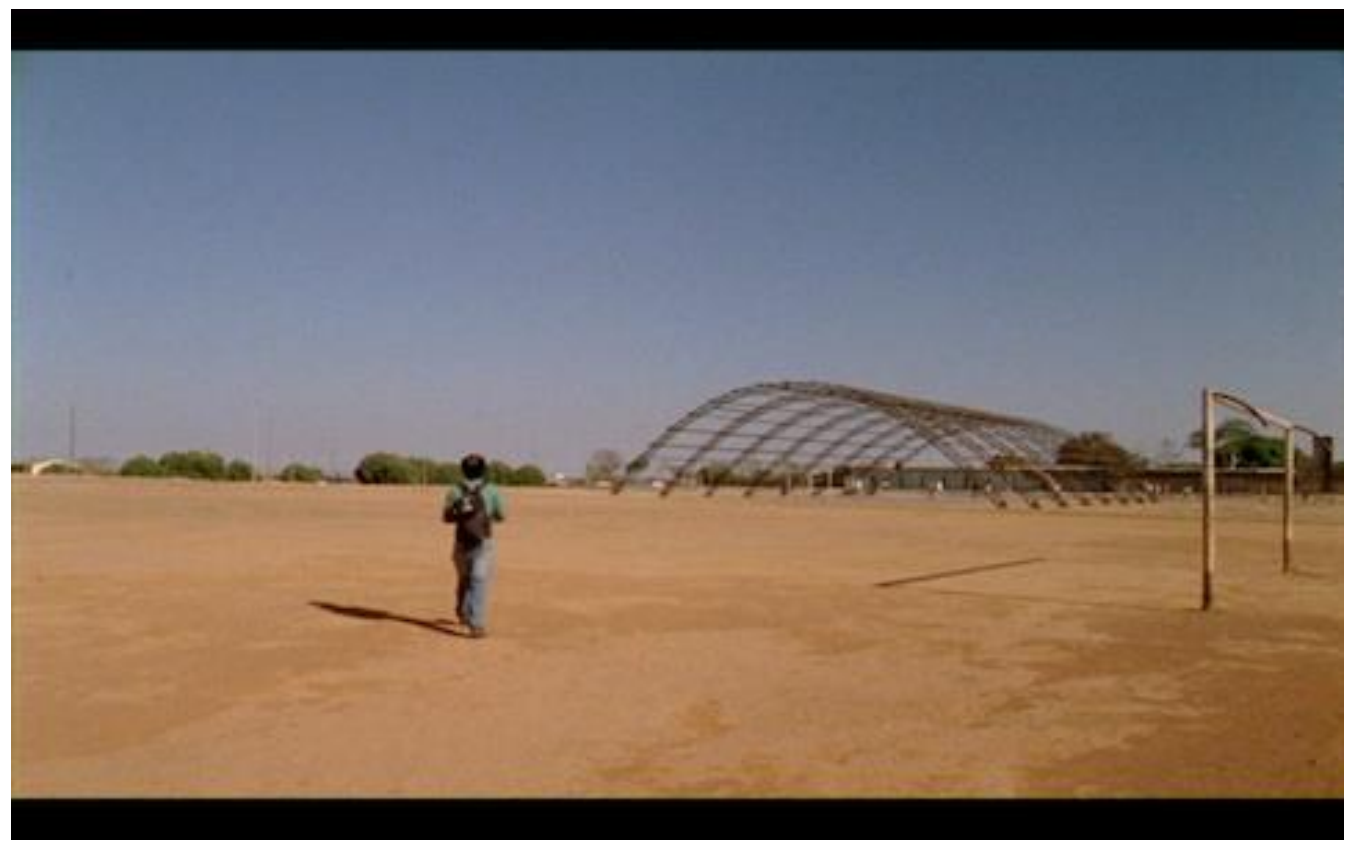

Imagem 1: Fotograma de A cidade é uma só?, de Adirley Queirós (2011). | Direitos cedidos por Adirley Queirós.

Ceilândia reage, e essa reação não deve se valer das armas de seu inimigo. Precisa, ao contrário, buscar forças em suas próprias potencialidades, notáveis, por exemplo, na caracterização de Dildu, um atípico candidato a deputado, que contrasta drasticamente com o perfil historicamente estabelecido dos políticos brasileiros. É de sexo masculino, mas ao invés de ser branco, vestir terno, empregar português formal e formular mirabolantes promessas de campanha, Dildu é negro, despenteado, veste-se informalmente, emprega gíria, 
dialoga com o rap e, sobretudo, faz propostas políticas extremamente claras e concretas (cinema por um real, preço do transporte público igual em Brasília e no entorno, indenização aos moradores expulsos do antigo Morro do Urubu, etc.).

A situação se agrava em Branco sai, preto fica. Passamos de um filme diurno a um filme noturno, de cenas externas ao confinamento doméstico, dos traslados de Dildu ao estado de sítio de Marquim (Marquim do Tropa) e Sartana (Cláudio Irineu Shokito). Aqui, corpos negros mutilados nos anos 1980 pela violência policial seguem atualmente privados de vida pública, de bem-estar, de condições de vida razoáveis. E quando já não há saída, resta apenas mandar tudo pelos ares ao som de black music. A reação em Branco sai, preto fica só pôde se dar por meio da apropriação de artifícios tecnológicos por sujeitos periféricos, como queria Milton Santos (2000). Marquim tem uma rádio pirata e faz gravações, Sartana desenha, esquadrinha e projeta imagens. Homens negros da periferia se unem para bombardear simbolicamente a capital brasileira com explosivo fabricado com sonoridades que têm justamente "a cara da Ceilândia", nas palavras do personagem Jamaika (DJ Jamaika) (01:00:06).

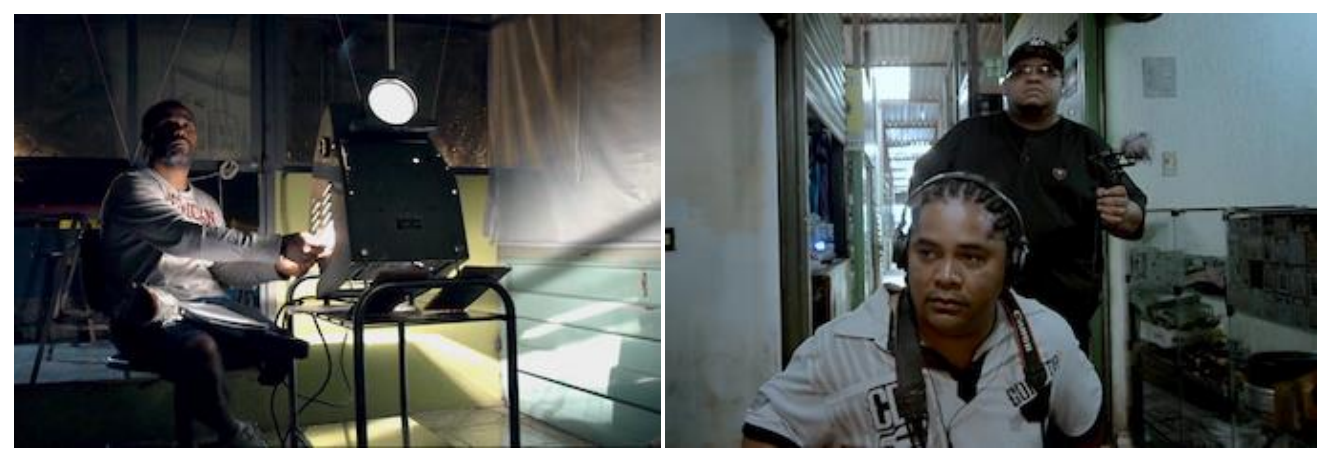

Imagens 2 e 3: Fotogramas de Branco sai, Preto fica, de Adirley Queirós (2014). | Direitos cedidos por Adirley Queirós.

A busca pela especificidade periférica, ou, mais especificamente, ceilandense, irriga também o estilo e a práxis de Adirley Queirós, que aposta na coletividade e na improvisação para fazer filmes sofisticados, altamente ficcionais, com baixos orçamentos destinados a documentários.

Assim, Adirley Queiros, Affonso Uchoa e André Novais, por meio de estilos variados, amparados em transformações conjunturais, 
desafiaram fronteiras historicamente estabelecidas no cinema brasileiro.

\section{Ilhas e fortalezas: infiltrar o território das elites e sabotar seu ponto de vista}

Se filmes como A cidade é uma só?, A vizinhança do tigre e Branco sai, preto fica apontam para a exclusão submetida aos moradores dos subúrbios, outras obras dão ênfase à reclusão voluntária das elites. $\mathrm{O}$ curta-metragem O Paraíso não é aqui (2003), realizado numa oficina de vídeo comunitário por um grupo de jovens moradores da maior favela de São Paulo (Paraisópolis), ${ }^{3}$ indica claramente que a elite evita tanto o olhar das câmeras quanto a relação com indivíduos que não pertencem ao seu estrato sócio-espacial. Além de denunciarem as condições de vida em seu bairro, os jovens cineastas desejam entrevistar moradores do bairro vizinho, o luxuoso Morumbi, reduto da elite paulistana. Tocam a campainha de várias casas, mas nunca são atendidos, a não ser por cães de guarda ou por moradores que se escondem tão logo compreendem o que se passa.

Afora os muros e grades que notamos nos casarões de O Paraíso não é aqui, o documentário Hiato (2008), de Vladimir Seixas, dá a ver a barreira invisível que cerca os locais frequentados e habitados pelas classes privilegiadas. O cineasta retoma os arquivos de uma manifestação que pode ser considerada como precursora do chamado rolezinho. ${ }^{4} \mathrm{Um}$ conjunto de pessoas pobres, moradoras de favelas, protestam contra sua condição precária de vida e de moradia através de uma excursão num shopping da zona sul do Rio de Janeiro destinado às classes abastadas. Sua presença é nitidamente inquietante, indesejável, chega a mobilizar os seguranças, causa repulsa e medo nos clientes e trabalhadores do local.

Se o acesso aos membros das classes privilegiadas e aos lugares por eles frequentados é árduo para indivíduos marginalizados, ele tampouco é simples aos cineastas de classe média que não aderem plenamente aos valores dominantes entre as elites. Por isso, embora estejam menos

\footnotetext{
${ }^{3}$ José Lusimar, Lucenilda dos Santos de Santana, Maria Borges, Nilcivan dos Santos de Santana, Renato de Paula Ferreira e Tiago da Silva Neves.

${ }^{4}$ Acerca do conceito de 'rolezinho' ver: https://pt.wikipedia.org/wiki/Rolezinho
} 
apartados da chamada "alta sociedade", realizadores como Marcelo Pedroso e Gabriel Mascaro inventaram o que Mariana Souto chamou de “dispositivos de infiltração” (Souto 2016). Conceberam subterfúgios para contornar barreiras físicas e virtuais impostas pelos mais ricos, ainda que para isso tivessem que lançar mão de estratégias ardilosas, tensionando a deontologia do documentário. Daí surgiram obras como Vista Mar (realizado coletivamente, ${ }^{5} 2009$ ); Câmara escura (Marcelo Pedroso, 2012); Um lugar ao sol (Gabriel Mascaro, 2009), que têm por alvo a esfera da morada; Pacific (Marcelo Pedroso, 2009); O Castelo (realizado coletivamente, ${ }^{6}$ 2015) e Doméstica (Gabriel Mascaro, 2012). De fato, Mascaro e os realizadores de Vista Mar dissimulam sua identidade, enquanto que Pedroso entrega anonimamente falsas encomendas. Se esses mecanismos concernem mais diretamente aos documentários, eles reverberam na trama de algumas ficções: em $O$ som ao redor, aqueles que se vingam do crime capitaneado por Francisco (Waldemar José Solha) se introduzem no universo do patriarca disfarçando sua identidade, enquanto que em Branco sai, Preto fica, homens negros da periferia falsificam passaportes para acessar à capital.

Mais do que simplesmente acessar aos redutos fortificados das classes privilegiadas, o intuito desses dispositivos é de aviltar o ponto de vista da elite sobre a realidade ao redor. Os locais de habitação são estratégicos nesse sentido, pois podem sugerir uma maneira de se relacionar (ou não) com o mundo exterior, assim como transparecer uma forma de enxergar o que está do lado de fora. Um lugar ao sol consegue, melhor do que Vista Mar, criar associações estéticas, por exemplo, entre o hermetismo dos imóveis e a ignorância demonstrada por certos moradores, ou mesmo entre a altura dos apartamentos e a altivez de seus donos. Quando, por exemplo, do alto de uma cobertura, a câmera se foca em alguns transeuntes, o enquadramento em plongée e a baixa definição das imagens (devido ao zoom digital) lembra os registros de câmaras de segurança. O filme sugere assim que do ponto de vista da cobertura, os "outros", aqueles que se encontram no espaço público, são percebidos como suspeitos. A partir de uma perspectiva tão distante, a individualização do outro se torna impossível, ou será

\footnotetext{
${ }^{5}$ Claugeane Costa, Henrique Leão, Pedro Diógenes, Rodrigo Capistrano, Rubia Marcia e Victor Furtado.

${ }^{6}$ Alexandre Wahrhaftig, Guilherme Giufrida, Helena Ungaretti e Miguel Antunes Ramos.
} 
deturpada, perdendo-se no amálgama do panorama, numa coletividade potencialmente ameaçadora.
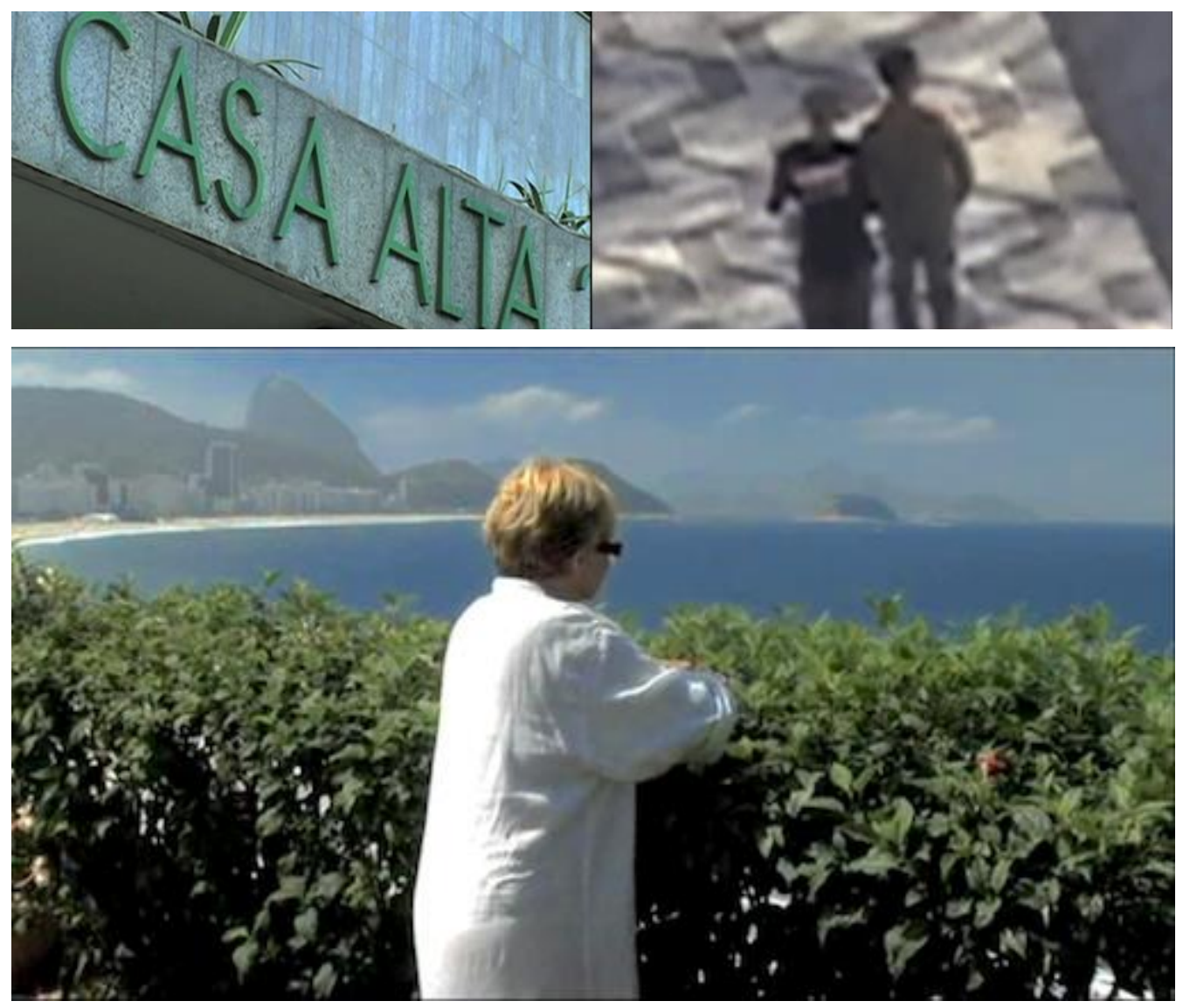

Imagens 4, 5 e 6: Fotogramas de Um lugar ao sol, Gabriel Mascaro, 2009. | Direitos cedidos por Gabriel Mascaro.

A despeito de seu aspecto quase pueril, Câmara escura também salienta a paranóia que rege a relação (ou a cisão) entre o espaço público, fonte de inquietação permanente, e os moradores de casarões de um bairro privilegiado. Em Vista Mar, Um lugar ao sol e Pacific, o desejo de se isolar se confunde com a iconografia edênica que foi historicamente projetada pelos colonizadores sobre as terras brasileiras. O ideal que se busca remete à ideia do paraíso tropical secularmente projetada sobre as terras brasileiras, ainda que o Jardim das Delícias em questão não passe de uma bolha ou de um oásis enquistado num mar de precariedade. Em Um lugar ao sol, o nome dos edifícios, todos de matriz europeia, confere historicidade à cidade atual, alude à colonização, tanto que a sequência que dá a ver tais topônimos se encerra com um prédio chamado 'Casa Alta', remetendo às antigas 'casas-grandes'. As 
vistas luxuriantes que se tem desde os apartamentos indicam que a elite se esforça para substituir aquilo que na cidade diz respeito ao território (conflitos sócio-espaciais) por uma perspectiva paisagística. De longe, do alto da cobertura, uma das entrevistadas em Um lugar ao sol enxerga a favela de Santa Marta como uma caixinha de brinquedos; tiros trocados entre duas comunidades viram fogos de artifício. De perto, o que vemos, porém, é a tragédia quotidiana das metrópoles brasileiras.

Esses filmes marcam, a partir de 2009, uma inflexão numa tendência que vinha se desenhando no cinema brasileiro desde o início dos anos 2000 -a dos chamados 'filmes-dispositivo' (Lins 2007). Obras como Um passaporte húngaro (Sandra Kogut, 2001) e 33 (Kiko Goifman, 2002) permitiram detectar tipos peculiares do fazer fílmico alcunhados de "dispositivos". No entanto, embora alguns filmes-dispositivo tenham conferido aos lugares e aos lares uma posição de destaque, como Rua de mão dupla (2002), de Cao Guimarães, e Acidente (2005), correalizado por Cao Guimarães e Pablo Lobato, a dimensão territorial desses não é flagrante. Já em dispositivos mais recentes, como o de Um lugar ao sol ou Projeto Torres Gêmeas ${ }^{7}(2011)$ e Câmara escura, os embates históricos e fraturas sociais passam a determinar a abordagem dos espaços e moradias. Eles revelam uma tomada de posição diante do elitismo e da plutocracia que emanam das formas das cidades e dos modos como são habitadas.

Isto posto, vale assinalar que, por vezes, esses dispositivos não demonstram interesse em realmente revelar aspectos pouco conhecidos das classes abastadas, limitando-se, simplesmente, a reiterar críticas já conhecidas a seu respeito. De certo modo, são como armadilhas que criam as condições ideais para captar algo previsto de antemão. ${ }^{8}$ Isso talvez se deva à dificuldade dos cineastas de assumir sua proximidade em relação às elites e classes médias - o que já era o caso na época do Cinema Novo. O desejo de afirmarem sua exterioridade chega a tornar as propostas destes cineastas simplistas. Em Câmara escura, por exemplo, quando uma moradora inquieta pergunta a Marcelo Pedroso onde ele mora, ele afirma que reside perto dali, num

\footnotetext{
${ }^{7}$ O curta-metragem Projeto Torres Gêmeas foi realizado coletivamente em 2011, montado a partir de materiais brutos anonimamente enviados por moradores da cidade de Recife que observam criticamente a presença de dois imensos arranha-céus (alcunhados de Torres Gêmeas) no centro histórico da capital pernambucana.

${ }^{8} \mathrm{O}$ filme-dispositivo que melhor escapa desse quadro é Doméstica.
} 
bairro vizinho (Parnamirim). Isso indica que, caso a abordagem adotada pelo cineasta fosse outra - se apresentando e explicando sua proposta -, ele talvez não tivesse tanta dificuldade em acessar esse meio - pelo menos, não tanta quanto a sentida pelos realizadores de $O$ Paraíso não é aqui. Pedroso poderia, assim, ter lidado com personagens mais profundos, registrando características menos evidentes. Ainda assim, isso não tira o mérito desses jovens cineastas, que começaram a preencher uma lacuna da história do cinema brasileiro ante as elites, sobretudo quando se trata de um cinema com vocação crítica.

\section{Coexistir no território urbano: sínteses ficcionais, releituras de Gilberto Freyre}

De um lado temos, assim, o isolamento das periferias, abordado por exemplo em A vizinhança do tigre, A cidade é uma só? e Branco sai, Preto fica. Do outro, o hermetismo das elites, desafiado por uma série de "dispositivos de infiltração". O resultado é um território urbano cindido, em que os extremos supostamente não comunicam. Daí a desertificação dos espaços públicos. No entanto, apesar de estarem apartados, a interação entre os bairros ditos nobres e as periferias é intensa, pois se certas elites evitam ao máximo o convívio com tudo e todos que não pertencem ao seu círculo, elas também carecem de mão de obra para manter seus privilégios. Essa 'concessão' é feita quando a convivência é selada por um acordo entre patrão e empregado, que estabelece uma hierarquia clara entre quem dá as ordens e quem as executa e compõe o principal ponto de contato entre os polos opostos da pirâmide social e da topografia urbana brasileira. Não é, pois, de admirar que a encontremos no cerne de filmes interessados pelas tensões que emanam dessa interação entre díspares, como $O$ som ao redor, Que horas ela volta? e Casa grande.

Essas três obras têm também em comum encenar tais relações no âmbito do lar, entrando em sintonia com um cenário mais amplo do cinema brasileiro do início dos anos 2010. Kleber Mendonça Filho, Anna Muylaert e Fellipe Barbosa elaboram um tipo de realismo social em que o habitar é revelador (como indica o étimo comum) daquilo a que Pierre Bourdieu chamou de habitus (Bourdieu 1972, 1980): o conjunto de práticas e bens (inclusive culturais) que distingue os grupos sociais. A relação entre patrões e empregados domésticos, que é particularmente complexa por frequentemente mesclar afetividade 
com exercício de poder, se mostra estratégica para encenar costumes paradoxais da sociedade brasileira. O som ao redor e Que horas ela volta? sinalizam que ela é fonte de diferentes tipos de mal-estar, pois conjuga proximidade física e abismo social, bem como afinidades sentimentais e preconceitos ancorados na história escravagista do país.

Esses paradoxos estão encarnados, de forma mais ou menos perspicaz, no roteiro e na mise-en-scène das obras, dando ensejo a dicotomias entre contato e ruptura, ou entre convivência e mandonismo, ou ainda entre acolhimento e menosprezo. Em $O$ som ao redor, por exemplo, fronteiras de diferentes ordens são constantemente afirmadas e contestadas. Se, por um lado, diversos planos reiteram grades, muros e dispositivos de segurança, por outro, essas barreiras são permanentemente transpassadas por personagens, sons, objetos e vultos. Essa interpenetração é reforçada pelo uso de formas fílmicas que poderíamos chamar de penetrantes, como o zoom in e o travelling, através das quais os espaços são interconectados. Kleber Mendonça Filho explicita que o isolamento almejado pela elite nunca será estanque. $\mathrm{O}$ medo seguirá sendo um afeto estruturante enquanto as classes populares forem negligenciadas. Fantasmas e vultos permanecerão ao redor, e a violência perdurará enquanto as injustiças e traumas históricos não forem remediados. Tal arranjo remete à "psicopatologia do Brasil entre muros", notada por Christian Dunker (2015), psicanalista atento ao cinema brasileiro. Dunker explica que na "lógica do condomínio" vigente na sociedade brasileira, ao invés de serem enfrentadas, as diferenças sociais e raciais são contornadas "por meio de um sutil código de circulação e de convivência apartada entre os serviçais e os moradores" (Dunker 2015, 50). O autor alega ainda que esse imbróglio não pode ser plenamente recalcado, que ele insistirá em retornar, em vir à tona, por vezes de forma agressiva, causando sofrimento e mal-estar. Essa 'psicopatologia brasileira' aparece nitidamente nas experiências de moradia concebidas pelos filmes.

Em Que horas ela volta?, a estadia de Jéssica (Camila Márdila), que não se enquadra exatamente no pacto patrão-empregado, perturba toda a ordem instaurada na casa em que sua mãe trabalha. E o conflito entre uma classe popular em ascensão e uma classe alta que se sente ameaçada aparece justamente nas condições de habitação reservadas a Jéssica. A jovem manifesta seu desejo de ser recebida no quarto de visitas, para a exasperação da dona da casa, Bárbara (Karine Teles). O estopim da divergência entre as duas ocorre quando Bárbara impõe 
uma demarcação definitiva separando a área de serviço, em que Jéssica deve permanecer confinada, e o resto da casa. Jéssica não se submete e abandona definitivamente a mansão, gesto que será posteriormente seguido por sua mãe. Jéssica pretende estudar, precisamente, arquitetura, afirmando que pode ser um instrumento de transformação social. Numa das cenas do filme, ela analisa a planta da casa opulenta dos patrões da mãe e aponta a posição inferiorizada do quarto de empregada.

A aposta da mise-en-scène na convivência entre sujeitos de universos sócio-espaciais opostos confere a $O$ som ao redor, Que horas ela volta? e Casa grande um forte poder de síntese. Podemos pensar que essas obras se esforçam para atualizar a iniciativa cinemanovista de elaborar microcosmos da conjuntura brasileira. Mas ao optar por ambientar suas tramas em habitações da elite em que convivem patrões e empregados, os cineastas travam sobretudo uma interlocução estreita com o legado de Gilberto Freyre. Reivindicada pelos cineastas, a referência a Freyre foi notada por diversos críticos e pesquisadores. Em Casa grande ela aparece desde o título, enquanto que, no caso do $O$ som ao redor, Kleber Mendonça Filho explica que a origem do projeto reside na tentativa de adaptar o universo de Casa-grande \& Senzala para o contexto de uma rua atual da cidade do Recife. ${ }^{9}$ Muito embora as semelhanças sejam numerosas, as diferenças entre os filmes e o pensamento do sociólogo são igualmente importantes (ainda que a maior parte das análises tendam a negligenciá-las). ${ }^{10}$ Tanto nos filmes quanto em Casa-Grande \& Senzala, as cisões, preconceitos e o exercício de poder entre patrões e empregados ou entre senhores e escravos coexistem paradoxalmente com a conivência, a imbricação e a intimidade. Mas é importante perceber que os cineastas tendem a inverter a ênfase de Freyre. Onde o sociólogo dá maior peso à complementaridade harmoniosa entre antagonismos, os filmes ressaltam (em diferentes graus) a relação de dominação, as aporias, as clivagens e o mal-estar. Freyre está preocupado em criar um alicerce positivo para a identidade do brasileiro: enaltece a miscigenação supostamente originária desse povo, salientando mais o equilíbrio entre opostos do que a subjugação de um

\footnotetext{
${ }^{9}$ https://m.folha.uol.com.br/ilustrissima/2013/02/1231445-no-quintal-de-kleber-mendonca-filho.shtml

${ }^{10}$ É importante lembrar que Casa-grande \& Senzala é um livro complexo e nuançado, de sorte que seu cotejo com os filmes (cotejo um tanto quanto desmedido, por conta da natureza distinta das obras) merece ser estudado com mais esmero. Para uma elaboração deste argumento, veja-se Zan (2020).
} 
pelo outro. Já os filmes, ao sublinharem o desarranjo social, se distanciam do viés elogioso para elaborar uma crítica, dando ensejo a um vetor de transformação. Assim, o senso de ruptura é mais importante nas obras cinematográficas.

Os cineastas se mostram mais severos com as classes dominantes, as interrogam, as cobram. Mesmo em Casa grande, em que Fellipe Barbosa tende a ser (auto)indulgente (e talvez até um pouco ingênuo) com seu protagonista e alter ego Hugo (Marcello Novaes), é necessário que Luiza (Bruna Amaya) rompa com o privilegiado Jean (Thales Cavalcanti). E se o afeto deste por seu antigo motorista, Severino (Gentil Cordeiro), é genuíno, isso não impedirá o ex-funcionário de processar seu patrão, pai de Jean, para fazer valer seus direitos trabalhistas. Em $O$ som ao redor, a atmosfera asfixiante não tem redenção possível. A violência e a vingança são a única teleologia que desponta no horizonte. Em Que horas ela volta?, a ascensão social e a recomposição familiar vislumbrada por Jéssica e Val (Regina Cazé) implicará, decerto, o acesso à universidade por parte de Jéssica, mas também a ruptura com a casa dos patrões (e com aquilo que ela representa).

Através desses embates mais ou menos evidentes entre detentores do poder e sujeitos historicamente marginalizados, os filmes parecem introduzir no universo freyriano algo do materialismo histórico marxista, calcado nos choques de interesse e na dominação entre classes, como se respondessem às incontáveis críticas sofridas por Freyre por parte de intelectuais alinhados a ideologias de esquerda.

\section{Considerações finais}

A partir de filmes majoritariamente realizados durante a última década, este texto apresenta algumas balizas do que teria sido uma guinada territorial do cinema brasileiro. Pareceu-nos importante estabelecer, de saída, uma distinção conceitual entre as noções de espaço e território. Preocupamo-nos, ainda, em atentar, mesmo que de forma lacunar e panorâmica, para propostas fílmicas diversificadas em que a relação entre estética e política é fortemente permeada por questões territoriais.

Constituímos três conjuntos de obras. O primeiro agrupamento tensiona cinematograficamente a ideia de periferia, bem como as expectativas e os imaginários hegemônicos atrelados ao universo 
suburbano. O prisma de análise adotado nesse conjunto torna evidente que a dimensão territorial do cinema não se restringe aos atributos estéticos dos filmes. A observação da trajetória de Adirley Queirós, Affonso Uchoa e André Novais permitiu inferir que a pretensa inclusão de jovens oriundos de periferias nos circuitos do cinema concerne apenas a alguns casos mais ou menos isolados de indivíduos que, contrariando as estatísticas, se beneficiaram de estudo superior em instituições bem qualificadas. Isso não impede que circulação de seus filmes represente um reordenamento da distribuição cinematográfica no que tange à dicotomia centro/periferia, o que reverbera nas mudanças paradigmáticas das políticas públicas relativas ao audiovisual operadas desde o início dos anos 2000. Já o segundo grupo responde ao desejo de dar a ver, criticamente, o universo recluso das classes mais abastadas. Uma série de documentários lança mão de dispositivos destinados a hackear o ponto de vista por vezes retrógrado de certas elites brasileiras. Entretanto, alguns dispositivos, como o de Câmara escura, Vista Mar ou Um lugar ao sol, reiteram ataques já conhecidos, formulados antes mesmo de confrontar o real. Isso talvez tenha a ver com o fato de que, nesses filmes, os documentaristas se isentam de refletir sobre seu próprio lugar de enunciação. Tendem a assumir uma posição radicalmente externa ao universo retratado, o que nem sempre condiz plenamente com os fatos. O terceiro agrupamento, por sua vez, reúne filmes de ficção em que indivíduos marginalizados e privilegiados coexistem, frequentemente em ambiente doméstico, ressaltando as relações de poder que existem no foro íntimo. Afora as semelhanças comumente notadas entre obras como $O$ som ao redor, Que horas ela volta? e a interpretação da sociedade brasileira formulada por Gilberto Freyre, indicamos também certas incongruências entre os filmes e o legado do famigerado sociólogo. Embora desproporcional, essa empreitada comparatista tem por escopo revelar nuances, evitar assimilações superficiais, reativando o potencial analítico desse cotejo regularmente estabelecido.

Através da análise desses três conjuntos de filmes brasileiros recentes, visamos esboçar o que poderia ser considerado como uma análise territorial dos filmes e do cinema. Importa frisar que aquilo que entendemos por 'território' tem força de sistema em determinada cinematografia brasileira recente (2009-2017), pois permite reunir incontáveis obras com características diversas. Temos consciência que para testar efetivamente o viés analítico que tentamos forjar seria necessário estudar as obras de forma mais detida. Para além disso, 
nossa empreitada poderia incluir outros conjuntos de obras não mencionados, tais como os filmes militantes que se insurgem contra a plutocracia que rege o urbanismo das metrópoles brasileiras, ${ }^{11} \mathrm{ou}$, como indicado na introdução, todo um leque de filmes territorialmente engajados que não estão sediados no contexto urbano. Não obstante, cremos que o prisma analítico que aqui propomos abre caminhos ao estudo do recente cinema brasileiro que merecem continuar a ser explorados.

\section{Referências}

Alvarenga, Clarisse. 2004. Vídeo e experimentação social: Um estudo sobre o vídeo comunitário contemporâneo no Brasil. Dissertação de mestrado em Multimeios. Campinas: Unicamp.

Bordwell, David,Thompson, Kristin e Staiger, Janet. 1988. The Classical Hollywood Cinema: Film style and mode of production to 1960. Londres e Nova Iorque: Routledge.

Bourdieu, Pierre. 1972. Esquisse d'une théorie de la pratique. Genebra: Droz.

. 1980. Questions de sociologie. Paris: Minuit.

Dunker, Christian. 2015. Mal-estar, sofrimento e sintoma: Uma pscicopatologia do Brasil entre muros. São Paulo: Boitempo.

Freyre, Gilberto. 2003 [1933]. Casa-grande \& Senzala: Formação da família brasileira sob o regime da economia patriarcal. São Paulo: Global.

Lacoste, Yves. 2003. De la géopolitique aux paysages: dictionnaire de la géographie. Paris: Armand Colin.

Lévy, Jacques. 1999. Le tournant géographique: penser l'espace pour lire le monde. Paris: Belin.

Lins, Consuelo. 2007. “O filme-dispositivo no documentário brasileiro contemporâneo”. In Sobre Fazer Documentários, organizado por Cláudia Mesquita, 434-51. São Paulo: Itaú Cultural.

Mesquita, Claudia. 2011. "Um drama documentário? Atualidade e história em A cidade é uma só”. Devires 8 (2): 48-69.

${ }^{11}$ Vide os filmes do movimento 'Ocupe Estelita': https://www.youtube.com/user/ocupeestelita 
Raffestin, Claude. 1980. Pour une géographie du pouvoir. Paris: Libraires techniques.

Santoro, Luiz Fernando. 1989. A imagem nas mãos: O vídeo popular no Brasil. São Paulo: Summus.

Santos, Milton. 2000. Por uma outra globalização: Do pensamento único à consciência universal. São Paulo: Record.

Souto, Mariana. 2016. Infiltrados e invasores: Uma perspectiva comparada sobre as relações de classe no cinema brasileiro contemporâneo. Tese de doutorado em comunicação. Belo Horizonte: Universidade Federal de Minas Gerais.

Toledo, Moira. 2010. Educação audiovisual popular no Brasil. Panorama (1990-2009). Tese de doutorado em comunicação. São Paulo: Universidade de São Paulo.

Zan, Vitor. 2019. Habiter la ville, faire territoire: une prise de position du cinema brésilien (2005-2017). Tese de doutorado em Estudos cinematográficos e audiovisuais. Paris: Université SorbonneNouvelle, Paris 3.

. 2020. "Releituras de Gilberto Freyre pelo cinema brasileiro", Rebeca: Revista Brasileira de Estudos de Cinema e Audiovisual 9 (1): 114-127. https://doi.org/10.22475/rebeca.v9n1.628

\section{FILMOGRAFIA}

A cidade é uma só? [longa-metragem]. Dir. Adirley Queirós, 2011, 79 mins.

Aquarius [longa-metragem]. Dir. Kleber Mendonça Filho, 2016, 146 mins.

A vizinhança do tigre [longa-metragem]. Dir. Affonso Uchoa, 2014, 95 mins.

Branco sai, preto fica [longa-metragem]. Dir. Adirley Queirós, 2014, 95 mins.

Brasil S/A [longa-metragem]. Dir. Marcelo Pedroso, 2014, 72 mins.

Câmara escura [curta-metragem]. Dir. Marcelo Pedroso, 2012, 25 mins.

Casa grande [longa-metragem]. Dir. Fellipe Barbosa, 2014, 107 mins.

Dizem que os cães vêem coisas [curta-metragem]. Dir. Guto Parente, 2012, 12 mins. 
Doméstica [longa-metragem]. Dir, Gabriel Mascaro, 2012, 75 mins.

Ela volta na quinta [longa-metragem]. Dir. André Novais, 2014, 108 mins.

Fort Acquario [curta-metragem]. Dir. Pedro Diógenes,2016, 6 mins.

Hiato [curta-metragem].Dir. Vladimir Seixas, 2008, 20 mins.

O som ao redor [longa-metragem]. Dir. Kleber Mendonça Filho, 2012, 125 mins.

Que horas ela volta? [longa-metragem]. Anna Muylaert,2015, 111 mins.

O Castelo [curta-metragem]. Dir. Alexandre Wahrhaftig, Guilherme

Giufrida, Helena Ungaretti et Miguel Antunes Ramos, 2015, 9 mins.

Pacific [longa-metragem]. Dir. Marcelo Pedroso, 2009, 73 mins.

Um lugar ao sol [longa-metragem]. Dir. Gabriel Mascaro, 2009, 65 mins.

Vista mar [curta-metragem]. Dir. Claugeane Costa, Henrique Leão, Pedro Diógenes, Rodrigo Capistrano, Rubia Marcia et Victor Furtado, 2009, 12 mins.

\section{A position taken by Brazilian cinema in urban territories (2009-2017)}

ABSTRACT This panoramic article is interested in three very heterogeneous groups of films that allow us to highlight the centrality of urban territory issues in recent Brazilian cinema (2009-2017). Despite the diversity of perspectives, the act of inhabiting becomes a point of convergence between social activism and artistic ambition in these films. Linked to the political dimension of space, the notion of territory gives rise to an analytical prism elaborated according to the aesthetic characteristics of films as varied as A vizinhança do tigre (2014), O som ao redor (2012), Branco sai, preto fica (2014), Um lugar ao sol (2009) and Que horas ela volta? (2015).

KEYW ORDS Territory; Brazilian cinema; inhabiting; city.

Recebido a 4-09-2020. Aceite para publicação a 23-02-2021.

aniki Ensaios | Essays 